УДК 632.7:635.655

DOI https://doi.org/10.32848/agrar.innov.2021.5.5

\title{
ФІТОСАНІТАРНИЙ МОНІТОРИНГ ШКІДЛИВОЇ ЕНТОМОФАУНИ ПОСІВІВ СОÏ В УМОВАХ РИСОВИХ ЗРОШУВАЛЬНИХ СИСТЕМ
}

\author{
ДУДЧЕНкО В.В. - доктор економічних наук, член-кореспондент Національної академії \\ аграрних наук України \\ https://orcid.org/10000-0001-8545-7904 \\ Інститут рису Національної академії аграрних наук України \\ СТРИгун О.О. - доктор сільськогосподарських наук \\ https://orcid.org/0000-0001-7315-1473 \\ Інститут захисту рослин Національної академії аграрних наук України \\ ПАЛАМАРЧУК Д.П. - кандидат сільськогосподарських наук, старший науковий \\ співробітник \\ https://orcid.org/0000-0003-2735-0556 \\ Інститут рису Національної академії аграрних наук України \\ ПАЛАМАРЧУК А.В. - науковий співробітник \\ https://orcid.org/0000-0001-9979-547X \\ Інститут рису Національної академії аграрних наук України
}

Постановка проблеми. Виробництво сої в Україні та світі характеризується стрімкими темпами зростання посівних площ і валових зборів зерна. Так, за даними Державної служби статистики, у період із 2000 по 2015 р. площа посівів сої в Україні збільшилася із 61 тис га до 2,1 млн га, або в 34,4 рази, зокрема на Поліссі - із 580 га до 163 тис га, у Лісостепу - з 33,5 тис га до 906 тис га, у Степу - 339 тис га до 342 тис га [1].

Останнім часом усе більшу увагу аграріїв привертає соя як найкращий попередник рису у короткоротаційних сівозмінах, оскільки витримує тимчасове затоплення, поліпшує структуру ґрунту та його родючість. Проте насичення сівозмін соєю призводить до накопичення комплексу специфічних шкідливих організмів. Посіви, які впродовж декількох років не уражувалися хворобами та не пошкоджувалися шкідниками, сьогодні вимагають усе більшої уваги з погляду фрітосанітарного моніторингу. Існуючі системи захисту у переважній більшості господарств не забезпечують ефрективний контроль розвитку та поширення шкідливої ентомофауни [2; 3].

Аналіз останніх досліджень і публікацій. Утрати врожаю зерна сої через вплив шкідливих організмів можуть сягати 30-40\%. У сприятливі для свого розвитку роки шкідники здатні знищити до 90\% урожаю. Їх чисельність і шкідливість у посівах сої проявляються у різному ступені впродовж усього вегетаційного періоду і за роками дуже варіює. У посушливі роки їх шкідливість помітніша [4].

Найчастіше спостерігається шкода від комплексу видів комах, що з'являються у посівах одночасно. Найбільш уразливі до ентомофагів рослини у початкову фазу розвитку: проростання насіння та сходи, період закладання генеративних органів, фази наливу й дозрівання зерна $[5 ; 6]$.

Шкодять посівам сої представники майже всіх рядів, але найбільш чисельними $€$ прямокрилі, напівтвердокрилі, бахромчастокрилі, твердокрилі, лускокрилі, двокрилі та акариморфні кліщі [7-10].

Мета. Мета дослідження - визначення видового складу ентомофрагів та виявлення домінуючих шкідни- ків посівів сої у короткоротаційних рисових сівозмінах Південного Степу України.

Матеріали та методика досліджень. Визначення видового складу шкідників сої проводили за відповідними методиками та визначниками [11-13]. Чисельність видів визначали за даними ентомологічного косіння сачком, аналізу рослинних проб, візуального огляду рослин.

Обстеження здійснювалися один раз на 3-7 днів, перші обліки-у третій декаді травня. Надослідній ділянці оглядали по п'ять рослин у 20 місцях. Використовували польовий метод дослідження із супутніми фенологічними спостереженнями та аналізами.

Результати досліджень. Аналіз отриманих даних свідчить, що найбільша кількість видів від загального числа комах фрітофрагів належить до ряду лускокрилі (Lepidoptera) - 38,0\%, акарифрормні (Acariformes) - 22,0\%, бахромчастокрилі (Thysanoptera) - 17,0\% та напівтвердокрилі (Hemiptera) - 10,0\%. Менш чисельними є представники ряду рівнокрилі (Homoptera) - 5,0\%, прямокрилі (Orthoptera) - 5,0\% та твердокрилі (Coleoptera) - 3,0\% (рис. 1).

За даними дослідження, у період вегетації у посівах сої в умовах рисових чеків найчисельнішими були представники ряду Лускокрилих (Lepidoptera), зафіксовано шість видів: метелик лучний (Margaritia sticticalis L.); сонцевик будяковий (чортополохівка) (Vanessa cardui L.); совка-гамма (Autographa gamma L.); совка люцернова (Chloridea viriplaca Hfn.); совка бавовникова (Helicoverpa armigera Hfn.); вогнівка акацієва (Etiella zinckenella Tr.). Найбільша чисельність на сої була шкідників із ряду Акариформні (Acariformes) - кліщ павутинний звичайний (Tetranychus urticae Koch.) пошкоджував рослини від фази сходів до кінця вегетації рослини. Бахромчастокрилі (Thysanoptera) - трипс тютюновий (Thrips tabaci Lind.). У посівах даної культури зустрічалися комахи з ряду Твердокрилі (Coleoptera): довгоносик смугастий бульбочковий (Sitona lineatus L.); довгоносик сірий щетинистий (Sitona crinitus Hfn.). Напівтвердокрилі, або клопи (Hemiptera), були представлені чотирма видами з різних родин: клоп 


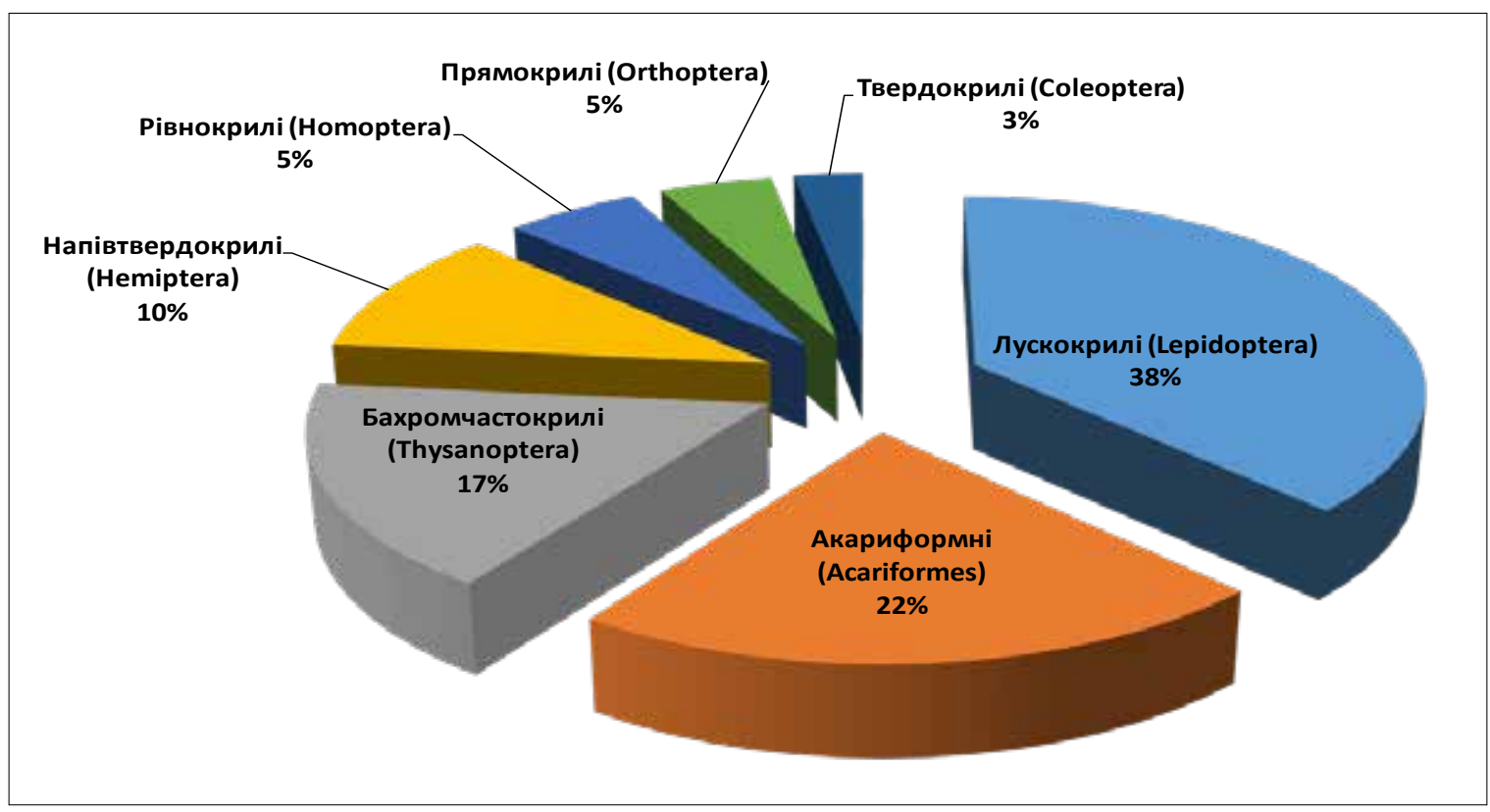

Puc. 1. Структура фimoфаzis

трав'яний (Lygus rugulipennis Popp.); клоп люцерновий (Adelphocoris lineolatus Goeze.); щитник люцерновий (Piezodorus lituratus F.); елія носата (Aelia rostrate Bsh.). Із ряду Рівнокрилі (Homoptera) посіви заселяли цикадка шестикрапкова (Macrosteles laevis Kib.); цикадка смугаста (Psammotettix striatus L.); попелиця велика злакова (Sitobion avenae F.). Із ряду Прямокрилі (Orthoptera) - коник зелений (Tettigonia viridissima L.); сарана мароканська (Dociostaurus maroccanus Thunb.); прус італійський (Calliptamus italicus L.). У посівах даної культури зустрічалися комахи із ряду Твердокрилі (Coleoptera): довгоносик смугастий бульбочковий (Sitona lineatus L.); довгоносик сірий щетинистий (Sitona crinitus Hfn.).

У результаті ентомологічних спостережень у 2018-2020 рр. було виявлено 20 видів шкідливих комах із семи рядів, 11 родин та один вид кліща (табл. 1).

Таблиця 1 - Видовий склад фітофагів сої в умовах рисових чеків (середнє, 2018-2020 рр.)

\begin{tabular}{|c|c|c|c|c|}
\hline № & Ряд & Родина & Вид & Частка у структурі, \% \\
\hline 1 & 2 & 3 & 4 & 5 \\
\hline 1 & \multirow{3}{*}{$\begin{array}{l}\text { Прямокрилі } \\
\text { Orthoptera }\end{array}$} & Tettigoniidae & Коник зелений (Tettigonia viridissima L.) & 3,0 \\
\hline 2 & & \multirow[t]{2}{*}{ Acrididae } & $\begin{array}{l}\text { Сарана Мароканська (Dociostaurus } \\
\text { maroccanusThunb.) }\end{array}$ & 0,2 \\
\hline 3 & & & Прус італійський(Calliptamus italicus L.) & 1,4 \\
\hline 4 & \multirow{3}{*}{$\begin{array}{l}\text { Рівнокрилі } \\
\text { Homoptera }\end{array}$} & \multirow{2}{*}{ Cicadine } & Цикадка шестикрапкова (Macrosteles laevis Kib.). & 0,3 \\
\hline 5 & & & Смугаста цикадка (Psammotettix striatus L.) & 0,2 \\
\hline 6 & & Aphidinea & Попелиця велика злакова (Sitobion avenaeF.) & 5,0 \\
\hline 7 & \multirow{4}{*}{$\begin{array}{l}\text { Напівтвердокрилі } \\
\text { Hemiptera }\end{array}$} & \multirow{3}{*}{ Miridae } & Клоп трав'яний ( Lygus rugulipennis Popp.) & 3,0 \\
\hline 8 & & & Клоп люцерновий (Adelphocoris lineolatus Goeze.) & 2,7 \\
\hline 9 & & & Щитник люцерновий (Piezodorus lituratus F.) & 3,3 \\
\hline 10 & & Pentatominae & Елія носата (Aelia rostrata Bsh.) & 1,5 \\
\hline 11 & \begin{tabular}{|l|} 
Бахромчастокрилі \\
Thysanoptera \\
\end{tabular} & Thripidae & Трипс тютюновий (Thrips tabaci Lind.) & 17,0 \\
\hline 12 & \multirow{2}{*}{$\begin{array}{l}\text { Твердокрилі } \\
\text { Coleoptera }\end{array}$} & \multirow{2}{*}{ Curculionidae } & Довгоносик смугастий бульбочковий (Sitona lineatus L.). & 2,0 \\
\hline 13 & & & Довгоносик сірий щетинистий (Sitona crinitus Hfn.) & 0,8 \\
\hline 14 & \multirow{6}{*}{$\begin{array}{l}\text { Лускокрилі } \\
\text { Lepidoptera }\end{array}$} & \multirow{4}{*}{ Noctuidae } & Совка-гамма (Autographa gamma L.) & 4,0 \\
\hline 15 & & & Совка люцернова (Chloridea viriplaca Hfn.) & 0,5 \\
\hline 16 & & & Сонцевик будяковий (чортополохівка) (Vanessa cardui L.) & 17,0 \\
\hline 17 & & & Совка бавовниква (Helicoverpa armigeraHfn.) & 0,7 \\
\hline 18 & & Phycitidae & Вогнівка акацієва (бобова) (Etiella zinckenella Tr.) & 7,0 \\
\hline 19 & & Pyraustidae & Метелик лучний (Margaritia sticticalis L.) & 8,4 \\
\hline 20 & $\begin{array}{l}\text { Акариформні } \\
\text { Acariformes }\end{array}$ & Tetranychidae & $\begin{array}{l}\text { Звичайний павутинний кліщ } \\
\text { (Tetranychus urticae Koch.) }\end{array}$ & 22,0 \\
\hline
\end{tabular}




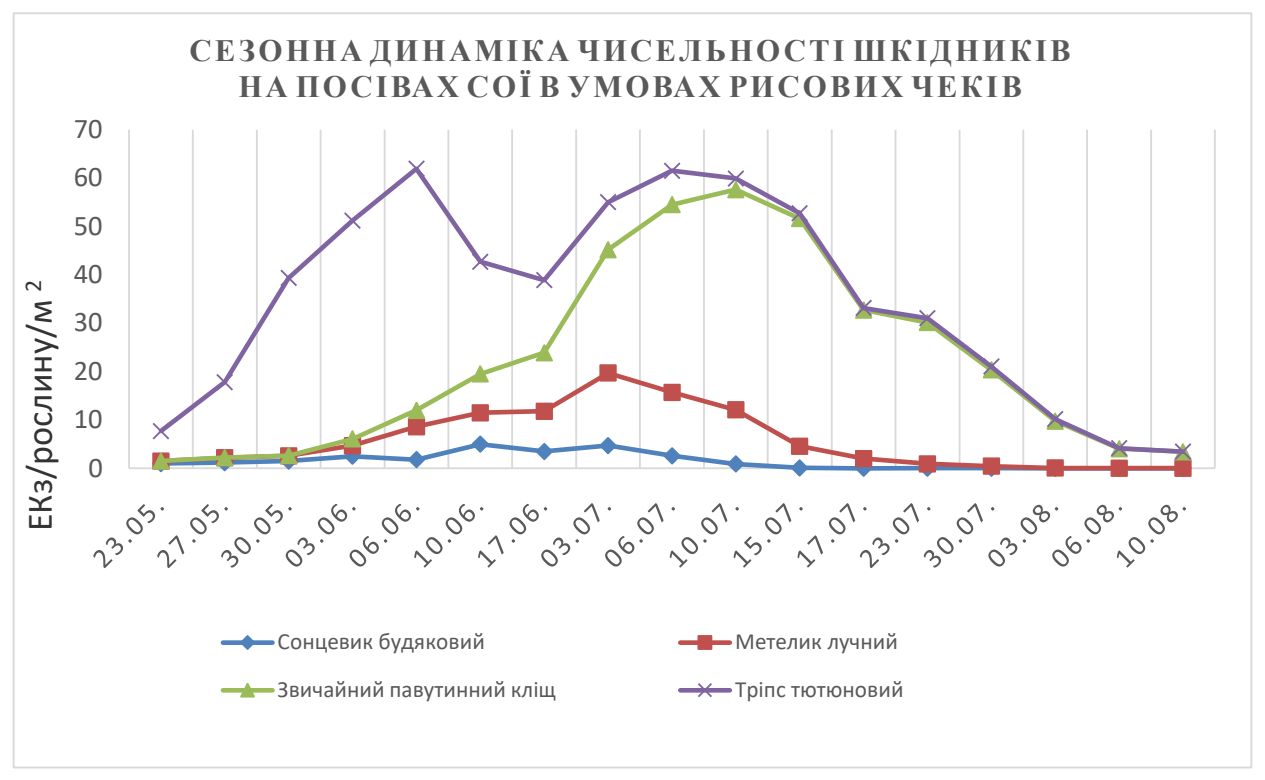

Рис. 2. Сезонна динаміка чисельності шкідників на посівах сої в умовах рисових чеків Південного Степу України

Серед фрітофрагів на сої одні види зустрічалися впродовж усього вегетаційного періоду культури, інші - лише на певних фазах ії̈ розвитку. Незважаючи на велику кількість їх видів головними були метелик лучний (Pyrausta sticticalis L), трипс тютюновий (цибулевий) (Thrips tabaci Lind.), звичайний павутинний кліщ (Tetranychus urticae Koch.) та сонцевик будяковий (чортополохівка) (Vanessa cardui L.) (рис. 2).

Наші спостереження за сезонною динамікою імаго сонцевика будякового (або чортополохівка) (Vanessa cardui L.) встановили від 0,01 до 5 екз./м². Шкідник перевищував ЕПШ 1 покоління гусениці у фазу ВВСН 12-15 розвиток листя та міжвузлів стебла у рослин сої.

Імаго метелика лучного показали, що кількість особин шкідника змінювалася залежно від фрази росту і розвитку рослин чисельність метелика лучного (Pyrausta sticticalis L.) становила від 0,03 до 15 екз./M². Імаго лучного метелика починали масовий літ у першій декаді травня.

Динаміка чисельності звичайного павутинного кліща (Tetranychus urticae Koch.) становила від 0,01 до 47 екз./ рослину. У 2019 р. були оптимальні умови для розвитку павутинного кліща, середньодобова температура становила $22-29^{\circ} \mathrm{C}$ та відносна вологість повітря до $60 \%$, яка співпадала з фазами цвітіння та формування бобів.

Найменша чисельність трипса тютюнового (або цибулевого) (Thrips tabaci Lind.) була у першу декаду серпня і становила 0,02 екз./M², а найбільша 50 екз./ $/ \mathrm{M}^{2}$

Таким чином, збільшення посівних площ сої в рисових зрошувальних системах вимагає дослідження комплексу фітофрагів та постійної уваги до нього через його несформованість і зростаючий рівень шкодочинності його представників.

Висновки. Кількість виявлених видів шкідників у посівах сої становила: ряд лускокрилих (Lepidoptera) -
38,0\%; 22,0\% - акарифрормні кліщі (Acariformes), бахромчастокрилі (Thysanoptera) - 17,0\%, напівтвердокрилі (Hemiptera) - 10,0\%, представники ряду рівнокрилі (Homoptera) - 5,0\%, прямокрилі (Orthoptera) - 5,0\% та 3,0\% - твердокрилі (Coleoptera).

Домінуючими видами в умовах рисових чеків були: метелик лучний (Pyrausta sticticalis L.) - 15 екз./ $\mathrm{M}^{2}$, трипс тютюновий (цибулевий) (Thrips tabaci Lind.) - 50 екз./м², звичайний павутинний кліщ (Tetranychus urticae Koch.) 47 екз./рослину, сонцевик будяковий (чортополохівка) (Vanessa cardui L.) - від 2 до 5 екз./м².

\section{СПИСОК ВИКОРИСТАНОЇ ЛІТЕРАТУРИ:}

1. Петриченко В.Ф., Лихочвор В.В. Рослинництво. Нові технології вирощування польових культур : підручник ; 5-е вид., виправ., доп. Львів : Українські технології, 2020. 806 с.

2. Продуктивність сої за різних способів і глибини обробітку ґрунту та доз добрив у сівозміні на зрошенні / М.П. Малярчук та ін. Зрошуване землеробство. 2019. Вип. 71. С. 100-104. URL: DOI: https://doi.org/10.32848/0135-2369.2019.71.21.

3. Дудченко Т.В., Дудченко В.В., Лісовий М.М. Сучасний стан та екологічний аналіз біорізноманіття рисових агроценозів Півдня України. Агроекологічний журнал. 2010. Спеціальний випуск. С. 88-92.

4. Бабич А.О., Бабич-Побережна А.А. Засуха, суховій i пилова буря в Україні в період глобальних змін клімату. Т. 1. Вінниця : ДІЛО, 2014. 468 с.

5. Сидоренко Т. Найпоширеніші шкідники й хвороби сої та рекомендації щодо захисту посівів. Пропозиція. 2010. № 6. С. 88-92.

6. Малярчук М.П., Шелудько О.Д., Марковська О.Є. Захист сільськогосподарських культур від шкідливих організмів в умовах Південного Степу України. Зрошуване землеробство. 2007. Вип. 47. С. 115-119.

7. Березовська-Бригас В.В. Люцерновий клоп (Adelphocoris lineolatus Goeze) на посівах сої у 
Центральному Лісостепу України. Карантин $i$ захист рослин. 2012. № 5. С. 25-26.

8. Морфологія, біологія шкідників бобових культур та заходи боротьби з ними в адаптивних технологіях вирощування : наукова монографія / І.М. Мринский та ін. Херсон : ОЛДІ-ПЛЮС, 2018. 90 с.

9. Шелудько О.Д., Марковська О.Є., Репілєвський Є.В. Ефективність захисту зрошуваних посівів сої від листогризучих совок. Зрошуване землеробство. 2013. Вип. 59. С. 79-81.

10. Ефективність пестицидів фрірми БАСФ на посівах сої в умовах зрошення Південного Степу України / О.Д. Шелудько та ін. Зрошуване землеробство. 2013. Вип. 60. С. 65-69.

11. Облік шкідників і хвороб сільськогосподарських культур / В. Омелюта та ін. ; за ред. В.П. Омелюти. Київ : Урожай, 1986. 2006 с.

12. Станкевич С.В., Забродіна І.В. Моніторинг шкідників сільськогосподарських культур. Харків, 2016. 216 с.

13. Сокол Т.В., Петренкова В.П. Определитель вредителей и болезней сои. Киев : Юнивест Медиа, 2013. 50 c.

\section{REFERENCES:}

1. Petrychenko, V.F. \& Lykhochvor, V.V. (2020). Roslynnytstvo. Novi tekhnolohii vyroshchuvannia polovykh kultur [Plant growing. New technologies for growing field crops]. Lviv: NVF "Ukrainski tekhnolohii" [in Ukrainian].

2. Malyarchuk, M.P., Tomnitskiy, A.V. \& Malyarchuk, A.S. et al. (2019). Produktivnlst soyi za riznih sposobiv i glibini obrobitku gruntu ta doz dobriv u sivozmini na zroshenni [Productivity of soybeans in different methods and depths of tillage and fertilizer doses in crop rotation under irrigation. Irrigated agriculture]. Zroshuvane zemlerobstvo - Irrigated agriculture, 71, 100-104 [in Ukrainian].

3. Dudchenko, T.V., Dudchenko, V.V. \& Lisoviy, M.M. (2010). Suchasniy stan ta ekologlchniy anallz bloriznomanlttya risovih agrotsenozlv Pivdnya Ukrayini [Current state and ecological analysis of biodiversity of rice agrocenoses of the South of Ukraine]. Agroekologlchniy zhurnal - Agroecological journal, special issue, 88-92 [in Ukrainian].

4. Babych, A.O. \& Babych-Poberezhna, A.A. (2014). Zasukha, sukhovii i pylova buria $v$ Ukraini $v$ period hlobalnykh zmin klimatu [Drought, dry wind and dust storm in Ukraine in the period of global climate change]. T. 1. Vinnytsia : «Vydavnytstvo - drukarnia DILO» [in Ukrainian].

5. Sydorenko, T. (2010). Naiposhyrenishi shkidnyky y khvoroby soi ta rekomendatsii shchodo zakhystu posiviv [The most common pests and diseases of soybeans and recommendations for crop protection]. Propozytsiia - Offer, 6, 88-92 [in Ukrainian].

6. Malyarchuk, M.P., Sheludko, O.D. \& Markovska, O.E. (2007). Zahist silskogospodarskih kultur vld shkidlivih organizmiv $v$ umovah Pivdennogo Stepu Ukrayini. [Protection of crops from pests in the southern steppe of Ukraine]. Zroshuvane zemlerobstvo - Irrigated agriculture, 47, 115-119 [in Ukrainian].

7. Berezovska-Brigas, V.V. (2012). Lyutsernoviy klop (Adelphocoris lineolatus Goeze) na posivah soyi u Tsentralnomu Lisostepu Ukrayini [Alfalfa bug
(Adelphocoris lineolatus Goeze) on soybean crops in the Central Forest-Steppe of Ukraine]. Karantin i zahist roslin - Quarantine and plant protection, 5, 25-26 [in Ukrainian].

8. Mrynskyi, I.M., Ursal, V.V., \& Kokovikhin, S.V. et al. (2018). Morfolohiia, biolohiia shkidnykiv bobovykh kultur ta zakhody borotby z nymy vadaptyvnykh tekhnolohiiakh vyroshchuvannia [Morphology, biology of legume pests and measures to control them in adaptive cultivation technologies]. Kherson: OLDI-PLIUS [in Ukrainian].

9. Sheludko, O.D., Markovska, O.E. \& Repilievskyi, Ye.V. (2013). Efektyvnist zakhystu zroshuvanykh posiviv soi vid lystohryzuchykh sovok [Effectiveness of protection of irrigated soybean crops from leaf-eating moths]. Zroshuvane zemlerobstvo - Irrigated agriculture, 59, $79-81$ [in Ukrainian].

10. Sheludko, O.D., Klubuk, V.V., Borovyk, V.O. \& Repilievskyi, Ye.V. et al. (2013). Efektyvnist pestytsydiv firmy BASF na posivakh soi $v$ umovakh zroshennia Pivdennoho Stepu Ukrainy [Efficacy of BASF pesticides on soybean crops under irrigation of the Southern Steppe of Ukraine]. Zroshuvane zemlerobstvo Irrigated agriculture, 60, 65-69 [in Ukrainian].

11. Omeliuta, V.P., Hryhorovych, I.V. \& Chaban, V.S. et al. (1986). Oblik shkidnykiv i khvorob silskohospodarskykh kultur [Accounting for pests and diseases of crops]. Kyiv : Urozhai [in Ukrainian].

12. Stankevych, S.V. \& Zabrodina, I.V. (2016). Monitorynh shkidnykiv silskohospodarskykh kultur [Monitoring of pests of agricultural crops]. Kharkiv [in Ukrainian].

13. Sokol, T.V. \& Petrenkova, V.P. (2013). Opredelytel vredytelei y boleznei soy [Determinant of pests and diseases of soybeans]. Kyev : «lunyvest Medya» [in Ukrainian].

Дудченко В.В., Стригун О.О., Паламарчук Д.П., Паламарчук А.В. Фітосанітарний моніторинг шкідливої ентомофауни посівів сої в умовах рисових зрошувальних систем

Мета. Визначення видового складу ентомофагів та виявлення домінуючих шкідників посівів сої у короткоротаційних рисових сівозмінах Південного Степу України. Методи. Польовий, лабораторний, розрахунково-порівняльний і статистичний. Результати. Отримано інформацію щодо видового складу шкідників у посівах сої та встановлено їх домінуючі види у короткоротаційних рисових сівозмінах: метеликлучний (Margaritia sticticalis L.), сонцевик будяковий, або чортополохівка (Vanessa cardui L.), клоп трав'яний (Lygus rugulipennis Popp.), клоп люцерновий (Adelphocoris lineolatus Goeze.), щитник люцерновий (Piezodorus lituratus F.), трипс тютюновий (Thrips tabaci Lind.), совка-гамма (Autographa gamma L.), совка люцернова (Chloridea viriplaca Hfn.), коник зелений (Tettigonia viridissima L.), прус італійський (Calliptamus italicus L.), попелиця велика злакова (Sitobion avenae F.), кліщ павутинний звичайний (Tetranychus urticae Koch.), сарана мароканська (Dociostaurus maroccanus Thunb.), цикадка шестикрапкова (Macrosteles laevis Kib.); цикадка смугаста (Psammotettix striatus L.), елія носата (Aelia rostrata Bsh.), довгоносик смугастий бульбочковий (Sitona lineatus L.), довгоносик сірий щетинистий (Sitona crinitus Hfn.), совка бавовникова (Helicoverpa armigera), вогнівка акацієва (Etiella zinckenella Tr.). Висновки. Кількість виявлених видів шкідників у посівах сої ста- 
новила: ряд лускокрилих (Lepidoptera) - 38,0\%; акариформні кліщі (Acariformes) 22,0\%, бахромчастокрилі (Thysanoptera) - 17,0\%, напівтвердокрилі (Hemiptera) 10,0\%, представники ряду рівнокрилих (Homoptera) -5,0\%, прямокрилих (Orthoptera) - 5,0\% та твердокрилих (Coleoptera) - 3,0\%. Домінуючими видами в умовах рисових чеків були: метелик лучний (Pyrausta sticticalis L.) 15 екз./M², трипс тютюновий (цибулевий) (Thrips tabaci Lind.) - 50 екз./M², звичайний павутинний кліщ (Tetranychus urticae Koch.) - 47 екз./рослину, сонцевик будяковий (чортополохівка) (Vanessa cardui L.) від 2 до 5 екз./м².

Ключові слова: шкідники, насіння, інсектицид, урожай, личинка, гусениця, чисельність, комаха.

Dudchenko V.V., Strigun O.O., Palamarchuk D.P., Palamarchuk A.V. Phytosanitary monitoring of harmful entomofauna of soybean crops in the conditions of rice irrigation systems

Goal. Determination of species composition of entomophages and detection of dominant pests of soybean crops in short-rotation rice crop rotations of the Southern Steppe of Ukraine. Methods. Field, laboratory, computational and statistical. Results. Information on the species composition of pests in soybean crops was obtained and their dominant species in short-rotation rice crop rotations were established: meadow butterfly (Margaritia sticticalis L.), sunflower tnisle (Vanessa cardui L.), grass bug (Lygus rugulipennis Popp). alfalfa bug (Carpocoris fuscispinus Boh.), alfalfa shield (Piezodorus lituratus F.), tobacco thrips (Thrips tabaci Lind.), gamma moth (Autographa gamma L.), alfalfa moth (Chloridea viriplaca Hfn.), grasshopper green (Tettigonia viridissima L.), Italian cockroach (Calliptamus italicus L.), large grass aphid (Sitobion avenae F.), spider tick (Tetranychus urticae Koch.), Moroccan locust (Dociostaurus maroccanus Thunb.), cicada six-spotted (Macrosteles laevis Kib.); striped cicada (Psammotettix striatus L.), nasal elia (Aelia rostrata Bsh.), striped tuberous weevil (Sitona lineatus L.), gray bristle weevil (Sitona crinitus $\mathrm{Hfn}$.), cotton moth (Helicoverpa armigera Hfn.), acacia firefly (Etiella zinckenella Tr.). Conclusions. The number of detected pests in soybean crops was: a number of scale insects (Lepidoptera) - 38.0\%; Acariform mites (Acariformes) $22.0 \%$, fringed (Thysanoptera) $-17.0 \%$, semi-hard-winged (Hemiptera) $-10.0 \%$, representatives of a number of isosceles (Homoptera) - 5.0\%, straight-winged (Orthoptera) - $5.0 \%$ and hard-winged Coleoptera $-3.0 \%$. The dominant species in rice checks were: meadow butterfly (Pyrausta sticticalis L.) 15 specimens $/ \mathrm{m}^{2}$, tobacco thrips (onion) (Thrips tabaci Lind.) -50 specimens $/ \mathrm{m}^{2}$, common spider mite (Tetranychus urticae Koch.) - 47 specimens / plant, painted lady butterfly (Vanessa cardui L.) - from 2 to 5 specimens / $\mathrm{m}^{2}$.

Key words: pests, seeds, insecticide, harvest, larva, caterpillar, number, insect. 